\title{
Penggunaan Metionin dan Lisinpada Pakan Mandiri Berbasis Bahan Baku Lokal Terhadap Pertumbuhan dan Efisiensi Pakan Pada Pembesaran Ikan Patin Siam (Pangasianodon hypophthalmus)
}

\author{
${ }^{* 1}$ Ediwarman, ${ }^{2}$ Syahrizal, dan ${ }^{1}$ Novita Panigoro \\ ${ }^{1}$ Perekayasa Madya pada Balai Perikanan Budidaya Air Tawar Jambi \\ ${ }^{2}$ Dosen Prodi Budidaya Peraairan Universitas Batanghari Jambi \\ ${ }^{1}$ Jln. Lingkar Selatan RT. 26 Kel. Paal Merah Kec. Jambi Selatan, Kota Jambi \\ ${ }^{2} J 1$. Slamet Riyadi, Broni Jambi, 36122. Telp. +6074160103 \\ ${ }^{* 1}$ e-mail korespondensi : ediwarman_05@yahoo.com
}

\begin{abstract}
The amino acids methionine and lysine are important protein elements for fish growth. This study aims to determine the effect of the use of methionine and lysine in independent feed based on local raw materials on the growth performance of Siamese catfish (Pangasianodon hypophtalmus). A total of 1,020 catfish with a weight of \pm 7.98 grams/head were reared in 12 units of hapa $(2 \times 2 \times 1,2 \mathrm{~m}, \mathrm{p} \times \mathrm{l} \times \mathrm{t})$ by $R A L$ with a stocking of $85 \mathrm{fish} / \mathrm{hapa}$. The level of use of methionine and lysine in the composition of the feed formulation was as follows: Treatment A (methionine 0\% + lysine 0\%), B (methionine 0\% + lysine $0.2 \%), C(0.2 \%$ methionine + lysine 0.3$) \%)$ and $D(0.2 \%$ methionine $+0.5 \%$ lysine $)$. During 56 days of rearing, survival did not affect the level of methionine and lysine in feed on rearing catfish. The results showed that the average final weight of fish increased with increasing levels of methionine and lysine in the feed, namely A.22.53; B.22.54; C.23.09 and D.24.78 grams/head. While growth (SGRAM) ranged from 1.84 to 2.03 grams/day-1, with feed conversion (FCR) ranging from 2.60 to 2.72. From the results of the analysis, it can be concluded that to obtain the best specific growth rate (SGRAM) of catfish, the use of methionine and lysine in independent feed at levels of $0.2 \%$ and $0.5 \%$ obtained a feed conversion ratio (FCR) of 2.61.
\end{abstract}

Keywords : Methionine, Lysine, Feed, Siamese Catfish

\begin{abstract}
Abtrak. Asam amino metionin dan lisin pakan unsur protein penting untuk pertumbuhan ikan. Penilitian ini bertujuan untuk mengetahui pengaruh penggunan metionin dan lisin pada pakan mandiri berbasis bahan baku lokal terhadap performan pertumbuhan ikan patin siam (Pangasianodon hypophtalmus). Sebanyak 1.020 ekor ikan patin dengan bobot \pm 7,98 gram/ekor dipelihara dalam 12 unit hapa $(2 \times 2 \times 1,2 \mathrm{~m}$, p x $1 \times \mathrm{t})$ secara RAL dengan pada tebar 85 ekor/hapa. Tingkat penggunaan metionin dan lisin dalam komposisi formulasi pakan adalah sebagai berikut : Perlakuan A (metionin 0\% + lisin 0\%), B (metionin 0\% + lisin $0,2 \%$ ), $\mathrm{C}$ (metionin $0,2 \%+$ lisin $0,3 \%$ ) dan $\mathrm{D}$ (metionin $0,2 \%+$ lisin $0,5 \%$ ). Selama 56 hari pemeliharaan, sintasan tidak berpengaruh terhadap tingkat pemberian metionin dan lisin dalam pakan pada pembesaran ikan patin. Hasil penelitian memberikan rerata bobot akhir ikan meningkat dengan meningkatnya tingkat pemberian metionin dan lisin dalam pakan yaitu sebesar A.22,53; B.22,54; C.23,09 dan D.24,78 gram/ekor. Sedangkan pertumbuhan (SGRAM) berkisar antara 1,84 - 2,03 gram/hari-1, dengan konversi pakan (FCR) berkisar antara 2,60 - 2,72. Dari hasil analisa dapat disimpulkan bahwa untuk mandapatkan laju pertumbuhan spesifik (SGRAM) ikan patin yang terbaik penggunaan metionin dan lisin dalam pakan mandiri pada kadar sebesar 0,2\% dan 0,5\% diperoleh rasio konversi pakan (FCR) sebesar 2,61.
\end{abstract}

Kata kunci : Metionin, Lisin, Pakan, Ikan Patin Siam

PENDAHULUAN

Usaha budidaya ikan air tawar di Sumatera telah berkembang sangat pesat, menjadi usaha budidaya yang intensif di karamba dan kolam. Namun dengan semakin mahalnya harga pakan komersial membuat budidaya ikan tersebut tidak berkembang dengan baik bahkan ada petani yang menutup usahanya, karena tingginya biaya produksi dimana 60\% - 80\% dari total biaya produksi berasal dari pakan (Mokoginta, $d k k$. 2006). Untuk menurunkan biaya produksi dari pakan, pembudidaya beralih ke pakan mandiri yang lebih murah. Pakan mandiri yang dibuat oleh pembudidaya berbahan baku lokal. Bahan baku lokal yang dominan digunakan adalah bahan nabati seperti dedak padi, bungkil kelapa, dan lainnya.

Bahan baku nabati lainnya yang banyak di Sumatera adalah bungkil kelapa sawit. Dari hasil penelitian Abidin, $d k k$ (2000) menyimpulkan bahwa PKM dapat digunakan sebanyak 8\% dalam pakan ikan lele (Clarias sp). Sedangkan menurut Afifah, $d k k$. (2006) menyimpulkan bahwa penggunaan protein bungkil kelapa sawit dalam pakan ikan patin jambal dapat mencapai hingga $10 \%$ protein bungkil kelapa sawit, sedangkan untuk jumlah bungkil kelapa sawit dalam pakan dapat mencapai $27 \%$ bobot kering atau hingga $40 \%$ bobot basah.

Bungkil kelapa sawit bisa diberikan kepada unggas (ayam dan bebek) sebesar maksimum 20\%, kepada babi 25-30\% kepada ikan 30-40\% kepada ternak ruminansia 30-50\%, komposisi yang tepat tentu tergantung dari bahan pendamping lainnya. Dengan pembuatan pakan buatan sendiri dari bahan baku PKM diharapkan dapat menekan biaya produksi pembesaran ikan patin.Namun, pakan yang berkualitas harus memenuhi 5 unsur nutrisi penting yaitu protein, lemak, karbohidrat, vitamin dan mineral. 
Protein dalam pakan tersusun dari berbagai asam amino. Asam amino penyusun protein dapat dibedakan menjadi dua yaitu asam amino esensial (arginin, histidin, isoleusin, leusin, lisin, metionin, fenilalanin, treonin, triptofan, dan valin) dan asam amino non esensial (alanin, prolin, glisin, serin, sistein, tirosin, asparagin, glutamin, asam aspartat, dan asam glutamat). Asam amino esensial atau asam amino eksogen termasuk asam amino yang harus ada dalam bahan pakan dan tidak dapat dibuat di dalam tubuh. Asam amino non esensial atau asam amino endogen adalah asam amino yang secara normal dapat disintesa dalam tubuh dengan cukup untuk memenuhi kebutuhan ikan.

Metionin adalah asam amino esensial yang mengandung sulfur, sebuah zat yang diperlukan tubuh untuk antioksidan alami (Dani, 2005 dan Alissianto, 2017). Lisin dengan rumus kimia C6H14N2O2 termasuk salah satu asam amino esensial pembatas dalam pakan bila tepung ikan digantikan oleh sumber protein nabati. Kebutuhan asam amino esensial lisin untuk tubuh ikan antara 4-6\% dari protein ransum, sedangkan ikan omnivora sebesar 2,07\% (Agustono, 2019).

Ketersediaan metionin dan lisin pada pakan komersial memungkinkan untukpenguranganbiayaefektifpakan, protein kasar tanpa mempengaruhi kinerja pertumbuhan ikan dan suplementasi pakan lisin efektif dalam peningkatan respon imun. Lisin dan metionin memberikan respon yang baik terhadap laju pertumbuhan spesifik, konversi pakan, dan efisiensi pakan pada kepiting bakau dengan dosis lisin dan metiionin sebesar 3\% dengan perbandingan antara lisin dan metionin 1:1 (Alissianto, 2017).

Dengan demikian, penambahan metionin dan lisin dapat memberikan peningkatan fekunditas, imunitas yang lebih baik dan pertumbuhan yang lebih cepat. Hal ini diharapkan dapat mengurangi penggunaan tepung ikan dan minyak ikan yang harganya semakin mahal. Namun, aplikasinya pada ikan air tawarbernilaiekonomisseperti ikan nila, mas dan patin belum diketahui pengaruhnya terhadap pertumbuhan dan efisiensi pakans ehingga perlu dilakukan penelitian penambahan metionin dan lisin pada pakan mandiri berbasis bahan baku local. Tujuan dari kegiatan ini adalah untuk menganalisis efektifitas penggunaan metionin dan lisin dalam pakan mandiri yang diformulasi dari beberapa bahan baku lokaluntuk pembesaran ikan patin siam (Pangasianodon hypophthalmus) terhadap pertumbuhan dan efisiensi pakan.

\section{METODOLOGI PENELITIAN}

Kegiatan ini akan dilaksanakan pada bulan Januari - Desember 2020 dan bertempat di Balai Perikanan Budidaya Air Tawar Sungai Gelam Jambi.Ikan uji yang dgunakan dalam kegiatan ini adalah benih patin ukuran 4inci dengan bobot rata-rata7,98 gram/ekor, dengan bobot berkisar antara 7,32-8,52 gram/ekor.Metionin yang akan digunakan merupakan produksi Sumitomo dengan kemasan $25 \mathrm{~kg} / \mathrm{zak}$ dan lisin yang merupakan produksi CJ kemasan $25 \mathrm{~kg} / \mathrm{zak}$.

Pakan uji yang digunakan dalam penelitian ini adalah pakan mandiri yang diformulasi dari beberapa bahan penyusun yang berbeda dengan kandungan protein sama $(28 \%)$ dan lemak sama $(9,04 \%)$ dengan penambahan metionin (M) dan lisin(L) berbeda seperti ditampilkan pada Tabel 1.

Tabel 1. Komposisi Formulasi Pakan Uji Dengan Kandungan Metionin dan Lisin Berbeda Bagi Ikan Patin Siam (Pangasianodon hypophthalmus)

\begin{tabular}{|c|c|c|c|c|c|}
\hline \multirow[b]{2}{*}{ No. } & \multirow[b]{2}{*}{$\begin{array}{l}\text { Komposisi Pakan } \\
\text { (gram/100 gram) }\end{array}$} & \multicolumn{4}{|c|}{ Perlakuan } \\
\hline & & $\begin{array}{c}\mathrm{A} \\
(\mathrm{M} 0,0+\mathrm{L} 0,0)\end{array}$ & $\begin{array}{c}\text { B } \\
(\mathrm{M} 0,2+\mathrm{L} 0,0)\end{array}$ & $\begin{array}{c}\mathrm{C} \\
(\mathrm{M} 0,2+\mathrm{L} 0,3)\end{array}$ & $\begin{array}{c}\mathrm{D} \\
(\mathrm{M} 0,2+\mathrm{L} 0,5)\end{array}$ \\
\hline 1 & Tepung ikan lokal & 30,00 & 30,00 & 30,00 & 30,00 \\
\hline 2 & Tepung kedelai & 20,00 & 20,00 & 20,00 & 20,00 \\
\hline 3 & Dedak halus & 15,00 & 15,00 & 15,00 & 15,00 \\
\hline 4 & Bungkil Kelapa/Kopra & 15,00 & 15,00 & 15,00 & 15,00 \\
\hline 5 & Tepung Jagung & 15,00 & 15,00 & 15,00 & 15,00 \\
\hline 6 & Tepung Tapioka & 2,00 & 2,00 & 2,00 & 2,00 \\
\hline 7 & Aminoliquid & 1,00 & 1,00 & 1,00 & 1,00 \\
\hline 8 & Vitamin mix & 1,50 & 1,50 & 1,50 & 1,50 \\
\hline 9 & Vitamin E (20mg/100) & 0,02 & 0,02 & 0,02 & 0,02 \\
\hline 10 & Enzym Pytase & 0,02 & 0,02 & 0,02 & 0,02 \\
\hline 11 & Cholin Chloride & 0,50 & 0,50 & 0,50 & 0,50 \\
\hline 12 & Ca. Diphosphate & 0,30 & 0,30 & 0,30 & 0,30 \\
\hline 13 & Anti Jamur & 0,05 & 0,05 & 0,05 & 0,05 \\
\hline 14 & Metionin & 0 & 0,20 & 0,20 & 0,20 \\
\hline 15 & Lisin & 0 & 0 & 0,30 & 0,50 \\
\hline & Jumlah & 100,39 & 100,59 & 100,89 & 101,09 \\
\hline
\end{tabular}


Ediwarman, Novita Panigoro, dan Syahrizal. Penggunaan Metionin dan Lisinpada Pakan Mandiri Berbasis Bahan Baku Lokal Terhadap Pertumbuhan dan Efisiensi Pakan Pada Pembesaran Ikan Patin Siam (Pangasianodon hypophthalmus)

\begin{tabular}{|l|l|c|c|c|c|}
\hline & Kadar Protein (\%) & 28,00 & 28,00 & 28,00 & 28,00 \\
\hline & Kadar Lemak (\%) & 9,04 & 9,04 & 9,04 & 9,04 \\
\hline & Kadar Serat (\%) & 11,04 & 11,04 & 11,04 & 11,04 \\
\hline & Kadar Abu (\%) & 5,65 & 5,65 & 5,65 & 5,65 \\
\hline & BETN* & 46,27 & 46,27 & 46,27 & 46,27 \\
\hline $\begin{array}{l}\text { Total Energi } \\
\text { (GE/Gramoss Energy) }\end{array}$ & 431,48 & 431,48 & 431,48 & 431,48 \\
\hline $\begin{array}{l}\text { Rasio energi/protein } \\
\text { (kkal GE/gram protein) }\end{array}$ & 15,41 & 15,41 & 15,41 & 15,41 \\
\hline
\end{tabular}

* Bahan Ekstrak Tanpa Nitrogen

Total energi (GE/Gramoss Energy) : dihitung berdasarkan nilai ekuivalen untuk protein 5,6 kkal g-1, lemak 9,4 kkal g-1, dan BETN 4,1 kkal g-1.

Wadah pemeliharaan yang digunakan adalah hapa berukuran $2 \times 2 \times 1,2 \mathrm{~m} 3$ yang dipasang di kolam berukuran $500 \mathrm{~m} 2$ dengan kedalaman air $\pm 1,5 \mathrm{~m}$, dirancang secara RAL (Rancangan Acak Lengkap).Untuk mengetahui pengaruh metionin dan lisin yang diberikan terhadap laju pertumbuhan harian, konversi pakan (FCR) dan kelangsungan hidup diuji dengan menggunakan analisis sidik ragam (ANOVA). Apabila terdapat berbeda yang nyata antar perlakuan dilanjutkan dengan uji beda nyata terkecil (Uji-Tukey HSD) untuk membandingkan antara perlakuan.

Pakan yang diberikan sebanyak $6 \% \mathrm{BB} / \mathrm{hari}$ atau dengan protein suplay $\pm 19 \mathrm{~g} \cdot \mathrm{kg}^{-1}$.hari ${ }^{-1}$. Frekuensi pemberian pakan dua kali sehari pada pukul 08.30 dan pukul 15.30 Wib. Sampling dilakukan untuk mengetahui bobot tubuh. Sampling pertama dilakukan pada awal percobaan dan selanjutnya setiap dua minggu sampai ikan mencapai ukuran $\pm 200 \%$ dari bobot awal atau setelah 2-3 bulan pemeliharaan. Jumlah ikan yang disampling sebanyak $100 \%$ dari populasi. Untuk menghitung jumlah biomassa dilakukan penimbangan terhadap total ikan dari masing-masing perlakuan di akhir percobaan.

Analisis kimia dilakukan parameter kualitas air yang diukur meliputi: suhu, $\mathrm{pH}$ dan oksigen terlarut dilakukan setiap hari pada pagi (pukul 07.00-08.00 wib) dan sore (pukul 15.00-16.00 wib.Analisa bahan meliputi analisa proksimat bahan pakan, pakan uji, tubuh ikan di awal dan diakhir percobaan, serta analisis beberapa kualitas air. Analisis proksimat bahan pakan, pakan uji, tubuh ikanterdiri dari protein, lemak, abu, air dan serat kasar. Bahan kering (DM) dikeringkan dengan oven pada suhu $135^{\circ} \mathrm{C}$ selama $2 \mathrm{jam}$, abu dengan pembakaran dalam muffle furnace pada suhu $600^{\circ} \mathrm{C}$ selama 2 jam. Kadar protein dianalisadengankjedahl line unit dan kadar lemak dianalis adengan lipid extraction unit.

Parameter yang diukur selama percobaan meliputi : bobot ikan, jumlah pakan yang diberikan, jumlah ikan yang ditebar dan hidup sampai akhir percobaan, serta kualitas air.Parameter lain yang diuji meliputi pertumbuhan, efisiensi pakan, serta kelangsungan hidup, sebagai berikut:

Untuk mengetahui laju pertumbuhan bobot harian ikan selama pemeliharaan dapat dihitung dengan persamaan (Halver, 2002):

$S G R=\frac{\operatorname{LnWt}-\operatorname{LnWo}}{\Delta t}$

Keterangan:

SGRAM = Laju pertumbuhan bobot harian (gramam/hari)

$\mathrm{Wt}=$ Bobot ikan pada akhir pemeliharaan (gramam)

Wo = Bobot ikan pada awal pemeliharaan (gramam)

$\Delta \mathrm{t} \quad=$ Lama waktu pemeliharaan (hari)

Untuk menghitung efisiensi pemberian pakan dapat dihitung dengan menggunakan rumus NRC (1977) sebagai berikut:

$$
F C R=\frac{F}{(W t+D)-W o}
$$

Keterangan :

$\mathrm{FCR}=$ Konversi pakan

$\mathrm{Wt}=$ Bobot ikan total pada akhir pemeliharaan (gramam)

Wo = Bobot ikan total pada awal penelitian (gramam)

$\mathrm{D}=$ Total bobot ikan yang mati selama penelitian (gramam) 
Untuk mengetahui efisiensi pemanfaatan pakan selama pemeliharaan dihitung dengan menggunakan rumus sebagai berikut :

$\mathrm{EPP}=\frac{W t-W o}{F} \times 100 \%$

Keterangan:

$\mathrm{Wt}=$ Bobot ikan pada akhir pemeliharaan $($ gramam $)$

Wo $=$ Bobot ikan pada awal pemeliharaan $($ gramam $)$

$\mathrm{F}=$ Jumlah pakan yang diberikan (gramam)

Untuk mengetahui tingkat kelangsungan hidup ikan selama pemeliharaan dihitung dengan menggunakan rumus Effendie (1997) sebagai berikut:

$$
S R=\frac{N t}{N o} \times 100 \%
$$

Keterangan:

$\mathrm{SR}=$ Kelangsungan hidup $(\%)$

$\mathrm{Nt}=$ Jumlah ikan pada akhir penelitian (ekor)

No = Jumlah ikan pada awal penelitian (ekor)

\section{Pertumbuhan}

\section{HASIL DAN PEMBAHASAN}

Perkembangan bobot tubuh ikan patin siam selama 56 hari percobaan menunjukkan adanya peningkatan bobot tubuh dari setiap perlakuan sampai akhir percobaan. Bobot tertinggi terdapat pada perlakuan D dengan penggunaan metionin $0,2 \%$ dan lisin $0,5 \%$ bobot rataan 24,78 gram/ekor, sedangkan bobot terendah terdapat pada kontrol perlakuan A yaitu metionin $0 \%$ dan lisin $0 \%$ sebesar 22,53 gram/ekor. Pertambahan bobot ikan patin siam dengan penggunaan metionin dan lisin yang berbeda pada pakan mandiri dapat dilihat pada Gambar 1.

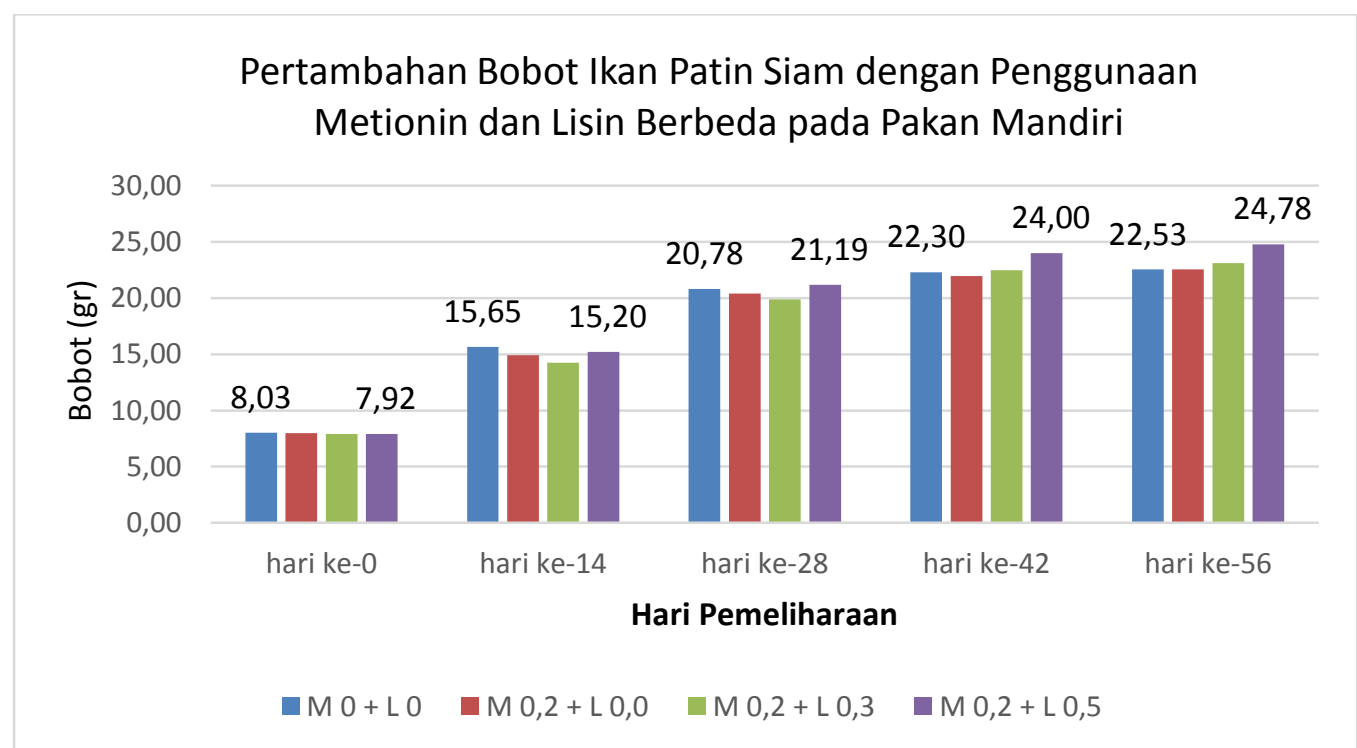

Gambar 1. Grafik pertambahan bobot ikan patin siam dengan penggunaan metionin dan lisin yang berbeda pada pakan mandiri selama 56 hari pemeliharaan

Laju pertumbuhan harian (Specific Gramowth Rate $=$ SGRAM) ikan patin siam selama 56 hari masa pemeliharaan pada penggunaan metionin dan lisin berkisar antara 1,84-2,03 gram/hari. Laju pertumbuhan harian tertinggi terdapat pada perlakuan D penambahan metionin $0,2 \%$ dan lisin $0,5 \%$ yaitu sebesar 2,03 gram/hari dan terendah terdapat pada kontrol yaitu metionin $0 \%$ dan lisin $0 \%$ sebesar 1,84 gram/hari. Laju pertumbuhan harian ikan patin siam dengan penggunaan metionin dan lisin yang berbeda pada pakan mandiri dapat dilihat pada Gambar 2. 


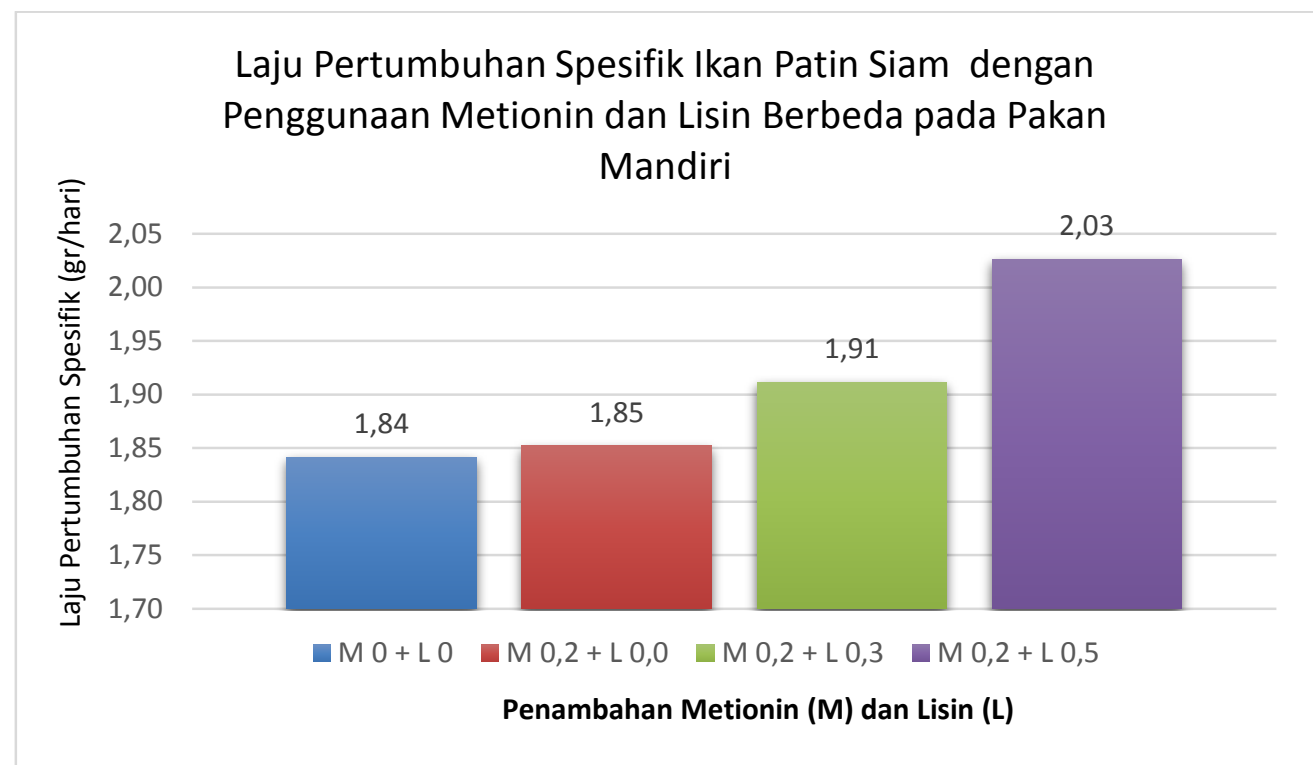

Gambar 2. Laju pertumbuhan spesifikikan patin siam dengan penggunaan metionin dan lisin yang berbeda pada pakan mandiri selama 56 hari pemeliharaan

Pertumbuhan ikan atau pembangunan jaringan baru ataupun perbaikan jaringan yang rusak selalu membutuhkan protein secara optimal. Menurut Suhenda, Setijaningsih dan Suryanti. (2005) bahwa pertumbuhan ikan patin djambal awal rata-rata 6,13 gram selama 42 hari terbaik dengan kadar protein $35 \%$ (2600 Kal) dengan nilai retensi protein maksimum (36,65\%). Pada penelitian ini, nilai kadar protein pakan semua perlakuan $28,00 \%$ sudah cukup memberikan penambahan pertumbuhan sel dan menganti sel yang rusak yang ditunjukan dengan laju pertumbuhan harian sebesar $1,84 \%-2,03 \%$. Protein total dalam pakan tidak mutlak menentukan pertumbuhan, namun dipengaruhi oleh asam yang dikandungnya atau ditentukan oleh keseimbangan nilai asam amino esensial dan non esensial. Nilai pertumbuhan yang baik dicapai pada perlakuan D (metionin 0,2\% dan lisin 0,5\%). Menurut Bokings $d k k$ (2017) bahwa kualitas protein pakan, terutama ditentukan oleh kandungan asam amino esensialnya, semakin rendah kandungan asam amino esensialnya maka mutu protein semakin rendah pula.

\section{Konversi Pakan}

Nilai konversi pakan menunjukkan efisiensi dalam pemberian pakan, nilai yang makin rendah menunjukkan bahwa pakan yang dimakan dapat dimanfaatkan oleh ikan patin siam dengan baik dan kualitas pakan yang digunakan lebih baik. Nilai konversi pakan pada penggunaan metionin dan lisin berkisar antara 2,4\%-2,6\% . berturutturut A (M 0\%+ L 0\%) 2,69, B (M 0,2\% + L 0\%) 2,59, C (M 0,2\% + L 0,3\%) 2,42, dan D (0,2 + L 0,5\%) 2,32. Nilai konversi pakan yang terendah terdapat pada penggunaan metionin perlakuan D (M 0,2\% dan L 0,5\%) sebesar 2,32\% dan tertinggi A (M 0\%+ L 0\%) 2,69\%. Nilai konversi pakan mandiri dengan penggunaan metionin dan lisin yang berbeda pada ikan patin siam dapat dilihat pada Gambar 3.

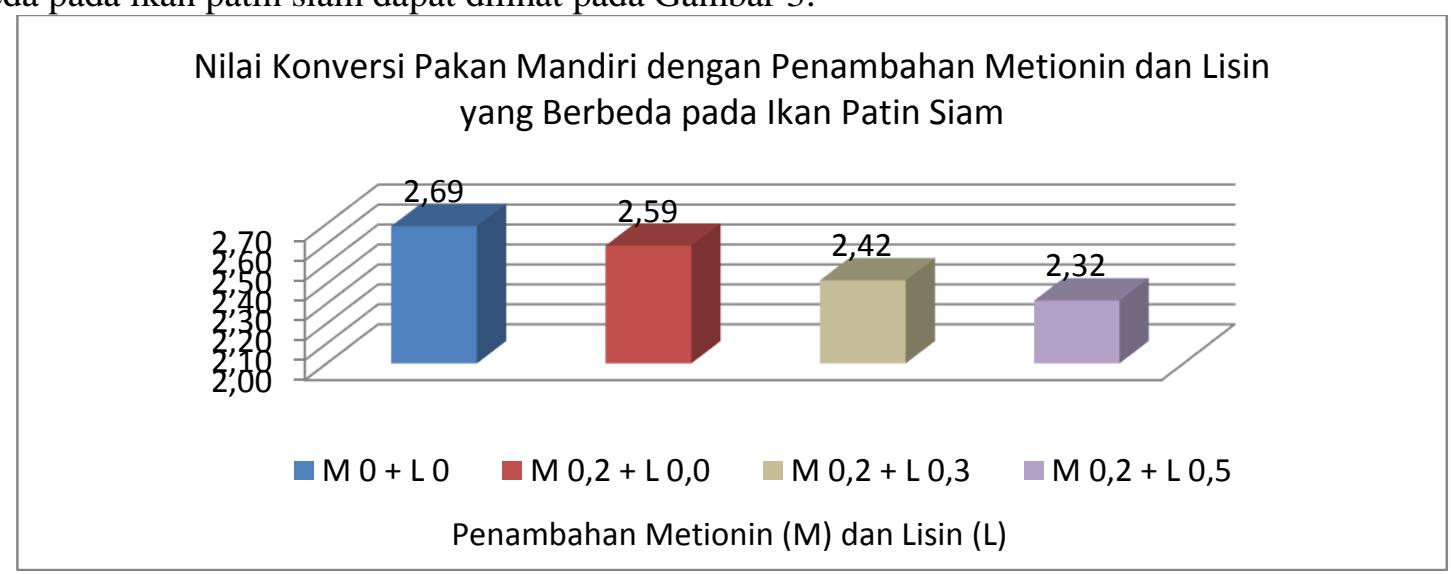

Gambar 3. Konvesi pakan mandiriikan patin siam dengan penggunaan metionin dan lisin yang berbeda selama 56 hari pemeliharaan

Nilai konversi pakan pada penelitian ini adalah 2,32\%-2,69\% (Gambar 3), menggambarkan bahwa peyerapan nutrisi bahan makanan dalam tubuh ikan patin tidak begitu baik, karenan jumlah pakan yang dikosumsi 
relatif besar berarti absorsi pakan menjadi rendah dan diduga banyak pakan yang diberikan tapi tidak dimakan oleh ikan. Suhenda $d k k$ (2005) menjelaskan bahwa pertumbuhan ikan patin 42 hari dengan berat awal 6,13 gram hari yang diberi pakan untuk kadar protein 30\%-40\% diperoleh rasio konversi pakan 1,31\%-1,36\% dengan tingkat pertumbuhan harian $3,64-3,82 \%$.

Nilai koversi terbaik antar perlakuan dalam peneltian ini ada pada perlakuan D (M 0,2 + L 0,5), hal ini diduga karena penambahan suplemen metionin dan lisin terlihat bahwa terjadi peningkatan kualitas pakan. Menurut Yang et al. (dalam Yusuf $d k k$, 2016) bahwa suplementasi lisin dan metionin dapat meningkatkan bobot tubuh akhir dan menurunkan FCR pada ikan grass carp, Ctenopharyngodon idella. Lisin berperan dalam penyedia energi, pertumbuhan tulang dan pembentukan otot. Pada proses penyediaan energi, lisin merupakan prekusor sintesis karnitin. Karnitin merupakan senyawa pembawa asam lemak rantai panjang dalam menembus membran mitokondria untuk proses $\beta$-oksidasi asam lemak. Penambahan lisin ke dalam pakan dapat meningkatkan terbentuknya karnitin sehingga terjadi peningkatan proses $\beta$-oksidasi untuk produksi energi dan pertumbuhan ikan meningkat (Li et al dalam Yusuf $d k k, 2016)$

Nilai efisiensi pemanfaatan pakan tertinggi dalam peneltian ini terdapat pada penggunaan perlakuan $\mathrm{C}$ (M $0,2 \%+\mathrm{L} 0,3 \%$ ) sebesar $42,87 \%$, sedangkan terendah terdapat pada kontrol perlakuan A sebesar 37,25\%. Efisiensi pemanfaatan pakan mandiri dengan penggunaan metionin dan lisin yang berbeda pada ikan patin siam dapat dilihat pada Gambar 4.

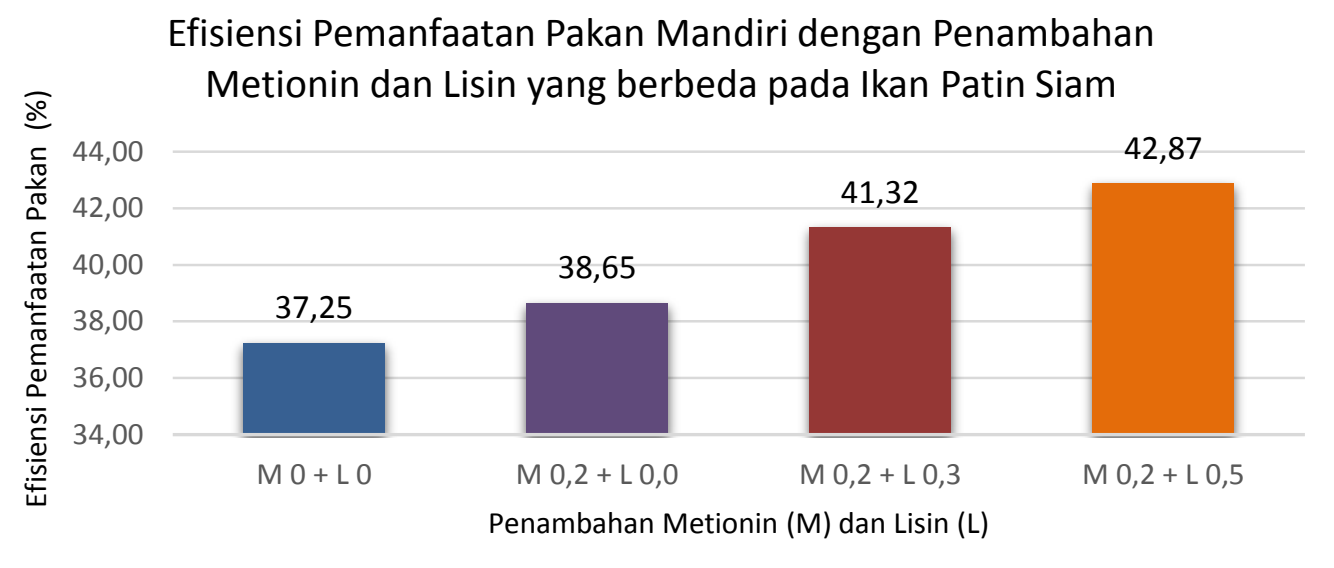

Gambar 4. Efisiensi pemanfaatan pakan mandiriikan patin siam dengan penggunaan metionin dan lisin yang berbeda selama 56 hari pemeliharaan

Gambar 4 menunjukkan bahwa belum dapat dimanfaatkan dengan baik oleh ikan patin siam karena ditujukan oleh efesiensi yang rendah berkisar 37,25\%-42,87\%. Efesiensi pemberian pakan yang baik harulah berda diatas nilai 75\%. Nilai efesiensi yang rendah ini diperkirakan oleh banyaknya pakan tidak dimakan oleh ikan kemungkinan disebabkan kurangnya nafsu makan sehingga pakan banyak terbuang. Pemeliharaan ikan patin dalam pemleliharaan secara air yang bersirkulasi diperoleh pertumbuhan bobot mutlak 5,93 gram-6,18 gram dengan laju pertumbuhan harian 4,21\%,- 4,32\%, diperoleh efisiensi pakan 91,23\%-94,31\% (Pasaribu $d k k, 2017$ ).

Untuk tren peningkatan kadar pemberian metionin dan lisin memberi semakin berpengaruh terhadap efesiensi pakan, hal ini diperkirakan semakin besar nilai tingkat efisiensi pemanfaatan pakan oleh tubuh ikan berarti nilai konversi pakan semakin kecil, sebaliknya apabila konversi pakan besar, maka tingkat efisiensi pemanfaatan pakan kurang baik. Dengan demikian tingkat efisiensi pemanfaatan pakan dapat pula menggambarkan nilai konversi pakan yang dicapai.

\section{Kelangsungan hidup}

Tingkat kelangsungan hidup ikan patin siam selama pemeliharaan berada pada kisaran $89-98 \%$ sehingga penggunaan metionin dan lisin pada pakan mandiri tidak menurunkan kelangsungan hidup ikan patin siam. Penggunaan metionin $0,2 \%$ dan lisin $0,5 \%$ perlakuan $\mathrm{D}$ memberikan kelangsungan hidup ikan patin siam tertinggi sebesar $97,25 \%$, sedangkan kelangsungan hidup ikan patin siam terendah pada kontrol tampa metionin dan lisin (perlakuan A) sebesar 89,41 dapat dilihat pada Gambar 5. 


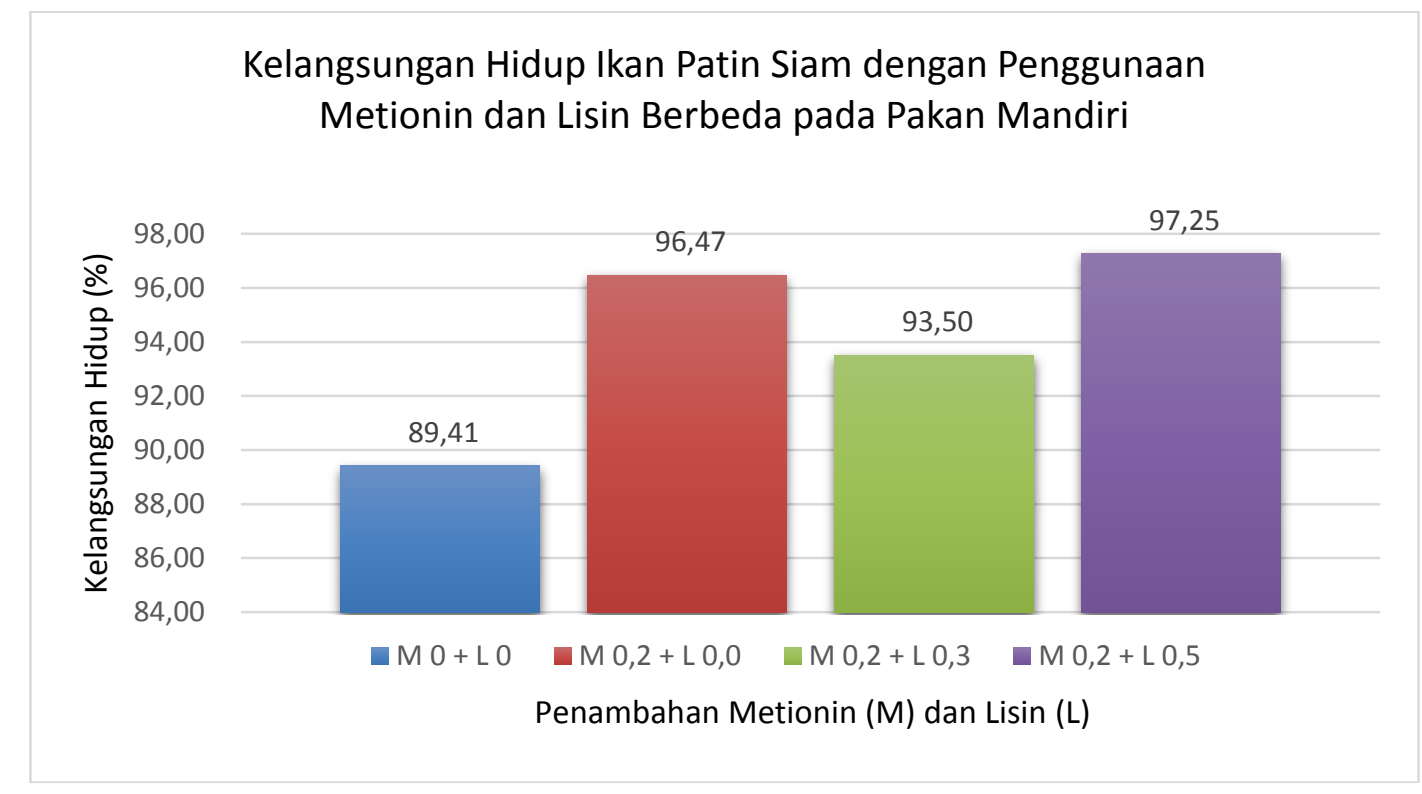

Gambar 5. Kelangsungan hidupikan patin siam dengan penggunaan metionin dan lisin yang berbeda selama 56 hari pemeliharaan

Tingkat kelangsungan hiup dalam peneltian ini pada gambar 5 mencerminkan tingkat kelulusan hidup sangat baik karena berada dalam nilai kelulusan hidup pada rentang 89,41\%-97,25\%. Tingginya tingkat kelulusan hidup ikan dalam penelitian ini banyak dipengaruhi selain mutu pakan yang relatif baik didukung oleh parameter kualitas air yang normal. Menurut Septimesy $d k k$ ( 2016) bahwa untuk percobaan terhadap padat 20 ekor/liter ikan patin (Pangasius sp.) panjang $3 \pm 0,5 \mathrm{~cm}$ dalam sistem resirkulasi dengan aliran air 0,1 liter/detik (suhu $26-38^{\circ} \mathrm{C}$, oksigen $6,66 \mathrm{mg} / \mathrm{L}-7,69 \mathrm{mg} / \mathrm{L}$, amonia 0,04-0,14 mg/L dan $\mathrm{pH}$ 6,5 - 8,5), pertumbuhan bobot absolut 1,03 \pm 0,43 gram dengan tingkat kelangsungan hidupnya 73,34 $\pm 4,30 \%$.

\section{Kualitas air}

Hasil pengukuran kualitas air menunjukkan bahwa kualitas air kolam selama pemeliharaan masih berada pada kisaran yang layak untuk budidaya ikan patin. Parameter kualitas air yang diukur antara lain suhu, $\mathrm{pH}$ dan oksigen terlarut. Berikut data kualitas air minimum dan maksimum hasil pengukuran selama pemeliharaan ikan patin siam dengan penggunaan metionin dan lisin yang berbeda pada pakan mandiri.

Tabel 2. Nilai maksimum dan minimum kualitas air ikan patin percobaan selama peneltian

\begin{tabular}{lcc} 
& \multirow{2}{*}{ Parameter } & \multicolumn{2}{c}{ Nilai } \\
\cline { 2 - 3 } & Minimum & Maksimum \\
\hline Suhu $\left({ }^{\circ} \mathrm{C}\right)$ & 26,2 & 29,0 \\
$\mathrm{pH}$ & 6,34 & 7,56 \\
Oksigen terlarut $(\mathrm{mg} / \mathrm{L})$ & 0,37 & 2,89 \\
\hline
\end{tabular}

Dari data tersebut di atas terlihat bahwa kualitas air media pemeliharaan ikan patin siam dengan penggunaan metionin dan lisin yang berbeda dalam pakan mandiri pada kisaran suhu 26,2-29, $0^{\circ} \mathrm{C}$, pH 6,34-7,56 dan oksigen terlarut 0,37-2,89 $\mathrm{mg} /$ liter. Kisaran nilai tersebut masih dapat dalam ditoleransi oleh ikan patin siam karena kelangsungan hidup ikan patin siam masih cukup tinggi yaitu 89-98\%. Menuru Syahrizal, $d k k$ (2018) bahawa selama pemeliharaan ikan patin yang diberi pakan difermentasi dengan M4 diperoleh tingkat kelangsungan hidup ikan 95\%$100 \%$ dengan kualitas air mediumnya suhu 26,5-26,9oC, pH 7,36-7,98, oksigen 5,00-6,90 mg/l, CO2 0,12-0,14 mg/l dan amonia 0,0001- 0,1210 mg/l.

\section{Nutrisi Pakan}

Nutrisi yang terkandung dalam pakan menentukan laju pertumbuhan dan kesehatan organisme ikan yang dipelihara, nilai konversi pakan dan efisiensi pemanfaatan pakan. Hasil analisa proksimat pakan uji dengan kandungan metionin dan berbeda seperti ditampilkan pada Tabel 3. 
Tabel 3. Hasil analisa proksimat pakan mandiri percobaan ikan patin dengan penggunaan metionin dan lisin

\begin{tabular}{|c|c|c|c|c|}
\hline Parameter & $\begin{array}{c}\text { Pakan A } \\
(\mathbf{M ~ 0 , 0}+\mathbf{L} \mathbf{0 , 0})\end{array}$ & $\begin{array}{c}\text { Pakan B } \\
(\mathrm{M} \mathrm{0,2}+\text { L 0,0) }\end{array}$ & $\begin{array}{c}\text { Pakan C } \\
(\mathrm{M} \mathrm{0,2}+\text { L 0,3) }\end{array}$ & $\begin{array}{r}\text { Pakan D } \\
(\mathrm{M} \mathbf{0 , 2}+\mathrm{L}, \mathbf{5})\end{array}$ \\
\hline Kadar Protein $(\%) * *$ & 26,10 & 25,73 & 25,85 & 26,20 \\
\hline Kadar Lemak (\%)* & 5,85 & 5,69 & 5,86 & 6,06 \\
\hline Kadar Serat $(\%)^{*}$ & 7,43 & 7,01 & 6,90 & 6,63 \\
\hline Kadar Abu (\%)* & 11,34 & 11,17 & 10,86 & 10,72 \\
\hline Kadar Air $(\%)^{*}$ & 11,35 & 12,09 & 13,50 & 11,83 \\
\hline $\mathrm{BETN} * * *$ & 49,28 & 50,40 & 50,53 & 50,39 \\
\hline Total energi (GE) & 403,2 & 404,21 & 407,02 & 410,28 \\
\hline $\begin{array}{l}\text { Rasio energi/protein } \\
\text { (kkal GE/g protein) }\end{array}$ & 15,45 & 15,71 & 15,75 & 15,66 \\
\hline
\end{tabular}

Total energi (GE/Gramoss Energy) : dihitung berdasarkan nilai ekuivalen untuk protein 5,6 kkal g-1, lemak 9,4 kkal g-1, dan BETN 4,1 kkal g-1.

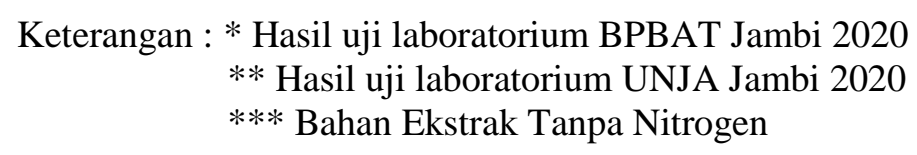

Nilai gizi hasil proksimat pakan pada Tabel 3 menjelaskan hasil komposisi formulasi pakam Tabel 1 menunjukan jenis makro-nutrien yang mempunyai nilai eneri seperti protein, lemak dan karbohidrat. Sementara itu, ikan membutuhkan kandungan protein dalam pakan dalam tingkat yang jauh lebih tinggi dibandingkan ke dua jenis makro-nutrien lainnya dalam masa pertumbuhan. Menurut Poernomo $d k k$ (1915) bahwa pertumbuhan dan kualitas daging ikan patin siam, Pangasianodon hypophthalmus yang diberi pakan komersial dengan kandungan protein berbeda. Ikan patin yang digunakan dengan bobot awal 33,61 gram ditebar sebanyak 30 ekor/hapa selama 60 hari. Penelitian ini didesain empat kandungan protein yang berbeda: pakan A (18\%), pakan B (23\%), pakan C (28\%), dan pakan D (32\%) didapat profil protein daging diperoleh pada perlakuan protein pakan $23 \%-32 \%$. Hasil penelitian ini menunjukkan bahwa perlakuan protein pakan 23\% memberikan kinerja pertumbuhan dan kualitas daging ikan terbaik. Nilai protein pakan relatif sama dengan nilai profil daging ikan yang diproksimat, artinya proses metabolisme dalam tubuh ikan berjalan dengan mudah dan lancar membentuk pertumbuhan daging.

\section{Analisa ekonomis}

Analisa usaha dihitung dari harga pakan yang diberikanan kepada ikan patin siam selama pemeliharaan 56 hari di hapa pemeliharaan di kolam dapat dilihat pada Tabel 5.

Tabel 5. Biaya pakan ikan patin siam yang diberi pakan dengan penggunaan metionin dan lisinberbeda pada pembesaran selama 56 hari di hapa.

\begin{tabular}{lcccc}
\hline \multirow{2}{*}{ Parameter } & \multicolumn{4}{c}{ Penggunaan Metionin dan Lisin, gram/100 gram } \\
\cline { 2 - 5 } & $\mathrm{M} 0,0+\mathrm{L} 0,0$ & $\mathrm{M} 0,2+\mathrm{L} 0,0$ & $\mathrm{M} \mathrm{0,2}+\mathrm{L} 0,3$ & $\mathrm{M} \mathrm{0,2}+\mathrm{L} \mathrm{0,5}$ \\
\hline Harga pakan (Rp./kg) & $6.421,00$ & $6.520,81$ & $6.610,81$ & $6.670,81$ \\
FCR & 2,69 & 2,59 & 2,42 & 2,32 \\
Biaya pakan (Rp./kg ikan) & $17.272,49$ & $16.888,89$ & $15.998,15$ & $15.476,27$ \\
Harga ikan (Rp./kg) & $17.000,00$ & $17.000,00$ & $17.000,00$ & $17.000,00$ \\
Laba kotor & $(-272,49)$ & 111,11 & $1.001,85$ & $1.523,73$ \\
\hline
\end{tabular}

Dari tabel tersebut diatas dapat dilihat bahwa dengan penggunaan metionin dan lisinberbeda dapat menurunkan biaya pakan, sehingga perlu dipertimbangkan penggunaan metionin dan lisin pada pakan ikan untuk usaha budidaya ikan patin siam. Nilai protein yang sama dengan penambahan metionin dan lisin membuat selisih pertumbuhan ikan patin meningkat secara linier. 
Ediwarman, Novita Panigoro, dan Syahrizal. Penggunaan Metionin dan Lisinpada Pakan Mandiri Berbasis Bahan Baku Lokal Terhadap Pertumbuhan dan Efisiensi Pakan Pada Pembesaran Ikan Patin Siam (Pangasianodon hypophthalmus)

\section{KESIMPULAN}

Penggunaan metionin dan lisinpada pakan mandiri berbasis bahan baku lokal terhadap pertumbuhan dan efisiensi pakan pada pembesaran ikan patin siam (Pangasianodon hypophthalmus) memberikan hasil sebagai berikut :

1. Laju pertumbuhan spesifik tertinggi terdapat pada perlakuan D penggunaan metionin $0,2 \%$ dan lisin $0,5 \%$ sebesar 2,03 gram/hari.

2. Nilai konversi dan efesiensi pakan diperoleh konversi terendah pada perlakuan $\mathrm{C}$ dengan metionin $0,2 \%$ dan lisin $0,3 \%$; dan tertinggi D metionin $0,2 \%$ dan lisin $0,5 \%$ sama-sama sebesar 2,43. Efisiensi pemanfaatan pakan tertinggi pada perlakuan D $(0,2 \%$ dan lisin $0,5 \%)$ sebesar $42,87 \%$.

3. Kelangsungan hidup ikan patin siam $\geq 90 \%$ diperoleh pada semua perlakuan kecuali kontrol sebesar $89,1 \%$.

4. Nilai penambahan mitionin dan lisin menyebabkan pertumbuhan meningkat secara linier dan nilai proksimat pakan relatif sama dengan profil daging ikan.

\section{DAFTAR PUSTAKA}

Abidin, Z; Ing Mokoginta dan Muhammad Agus Suprayudi. 2006. Pengaruh Kadar Tepung Bungkil Kelapa Sawit dalam Pakan Ikan Lele (Clarias sp). Tesis Sekolah Pasca sajana. IPB Bogor.53 Hal

Afifah, R; Ing Mokoginta Dan Yann Moreau 2006. Pernanfaatan Bungkil Kelapa Sawit dalam Pakan Juvenil ikan Patin Jambal Pangasius djambal.

Agustono. 2019. Peranan Lisin pada Pakan Ikan. http://fpk.unair.ac.id/peranan-lisin-pada-pakan-ikan/.

Alissianto Y. R. 2017. Pengaruh Pemberian Asam Amino Lisin dan Metionin pada Pakan Kepiting Bakau (Scylla serrata) terhadap Survival Rate (SR), Specific Gramowth Rate (SGRAM), Feed Convertion Ratio (FCR) dan Efficiency Feed (EF). Universitas Airlangga. Surabaya.

Ananda Tri, Diana Rachmawati, Istiyanto Samidjan. 2015. Pengaruh Papain pada Pakan Buatan terhadap Pertumbuhan Ikan Patin (Pangasius hypophthalmus). Journal of Aquaculture Management and Technology Vol. 4 No. 1 Tahun 2015 Hal. 47-53. http://ejournal-s1.undip.ac.id/index.php/jamt.

Bokings, U.L, Y. Koniyo, dan Juliana. 2017. Pertumbuhan Dan Kelangsungan Hidup Benih Ikan Patin Siam (Pangasius hypophthalmus) Yang Diberi Pakan Buatan, Cacing Sutra (Tubifex Sp.) dan Kombinasi Keduanya. Nikè. Jurnal Ilmiah Perikanan Dan Kelautan. Volume 5 Nomor 3. Hal 82-89. ISSN 2303-2200 Fakultas Perikanan Dan Ilmu Kelautan Universitas Negeri Gorontalo.

Khairuman. Amri, K. 2002. Membuat Pakan Ikan Konsumsi. Agramo Media Pustaka Jakarta.

Mokoginta et al. 2006. Bioteknologi pakan dalam akuakultur. Simposium Nasional. Bioteknologi dalam akuakulture. Bogor, 5 Juli 2006.

Mudjiman, A. 1984. Makanan Ikan. Penebar Swadaya Depok.

Murtidjo, BA. 2001. Pedoman Meramu Pakan Ikan. Penerbit KanisiusYogyakarta.

Septimesy, A , D. Jubaedah dan, A. D. Sasanti. 2016. Pertumbuhan Dan Kelangsungan Hidup Ikan Patin (Pangasius SP.) Di Sistem Resirkulasi Dengan Padat Tebar Berbeda. Jurnal Akuakultur Rawa Indonesia, 4 (1) :1-8 (2016) ISSN : 2303-2960. Hal. 1-8. PS.Akuakultur Fakultas Pertanian UNSRI.

Subandiyono, Subandiyono and Hastuti, Sri (2016) Buku Ajar Nutrisi Ikan. Universitas Diponegoro Press , Semarang, Indonesia. ISBN 978-602-1065-34-1

Suhenda, N, L. Setijaningsih dan Y. Suryanti. 2005. Pertumbuhan Benih Ikan Patin Jambal (Pangasius djambal) Yang Diberi Pakan Dengan Kadar Protein Berbeda. Berila Biologi. Volume 7. Nomor 4. Hal 101-199. Balai Riset Perikanan Budidaya Air Tawar.

Syahrizal, Safratilofa dan A M. Sopiana. 2018. Urgensi Perbedaan Waktu Fermentasi Em4, (Effective Microorganisms) Pada Bahan Pakan Untuk Ikan Patin (Pangasianodon hypophtalmus) Jurnal Akuakultur Sungai dan Danau Vol. 3 No. 1 Tahun 2018 Hal. 1 - 11 ISSN Print 2503-4766 ISSN Online 2597-8837 Program Studi Budidaya Perairan Fakultas Pertanian Universitas Batanghari.

Pasaribu, B M, Mulyadi, U.M. Tang. 2017. Pemeliharaan Ikan Patin Siam (Pangasius hypopthalmus) Dengan Sistem Resirkulasi Pada Wadah Dengan Bentuk Yang Berbeda. Jurnal Online Mahasiswa Fakultas Perikanan dan Kelautan Vol 4. No.2. ISSN: 2355 6900. Hal. 1-9.

Poernomo, N, N. B. P. Utomo, dan Z. I. Azwar. 2015. Jurnal Akuakultur Indonesia 14 (2), 104-111 (2015) Pertumbuhan dan kualitas daging ikan patin siam yang diberi kadar protein pakan berbeda. Jurnal Akuakultur Indonesia 14 (2). Hal. 104-111

Watanabe, T. Fish Nutrition and Mariculture. JICA Textbook The General Aquaculture course. Departement of Aquatic Biosciences Tokyo University of Fisheries

Yusuf, D. H, M. A. Suprayudi, dan D. Jusadi. 2016. Peningkatan Kualitas Pakan Ikan Nila Berbahan Tepung Bungkil Biji Karet Melalui Suplementasi Asam Amino. Jurnal Akuakultur Indonesia 15 (1), hal. 63-69, 
Ediwarman, Novita Panigoro, dan Syahrizal. Penggunaan Metionin dan Lisinpada Pakan Mandiri Berbasis Bahan Baku Lokal Terhadap Pertumbuhan dan Efisiensi Pakan Pada Pembesaran Ikan Patin Siam (Pangasianodon hypophthalmus)

DOI: 10.19027/jai.15.63.69. Departemen Budidaya Perairan, Fakultas Perikanan dan Ilmu Kelautan, Institut Pertanian Bogor Kampus IPB Dramaga Bogor. 